\title{
Comparative Study of Lisinopril Versus Telmisartan Effects on Oxidative Stress in Diabetic Type 2 Hypertensive Patients
}

\author{
Osama A. Hasan Fadhel A. Al-Hammami \\ Department of Pharmacology \\ College of Medicine \\ University of Mosul
}

(Received 11/10/2011;Accepted 26/12/2011)

\begin{abstract}
The present study was performed in order to compare the efficacy of lisinopril against telmisartan on oxidative stress represented by serum malondialdehyde (MDA) and total antioxidants status (TAS) in already diabetic newly diagnosed hypertensive patients. It was organized according to a randomized controlled comparative trial during the period of the study from November 2010 to June 2011. The current study included 82 patients, 43 took lisinopril ( $5 \mathrm{mg} /$ day), 39 enrolled with telmisartan $(40 \mathrm{mg} /$ day). In addition to 48 apparently healthy persons taken as controls. Serum levels of MDA and TAS were estimated before and after one month of therapy for patients, and at baseline only for controls. In the present study type 2 diabetic hypertensive patients revealed a significant rise in serum MDA and TAS at baseline stage, however, one month monotherapy with either lisinopril or telmisartan result in a significant improvement in both above parameters. The final conclusion of the study was that both lisinopril and telmisartan are able to subside oxidative stress in diabetic hypertensive patients.
\end{abstract}

Keywords: hypertension; diabetes mellitus; malondialdehyde; total antioxidant status.

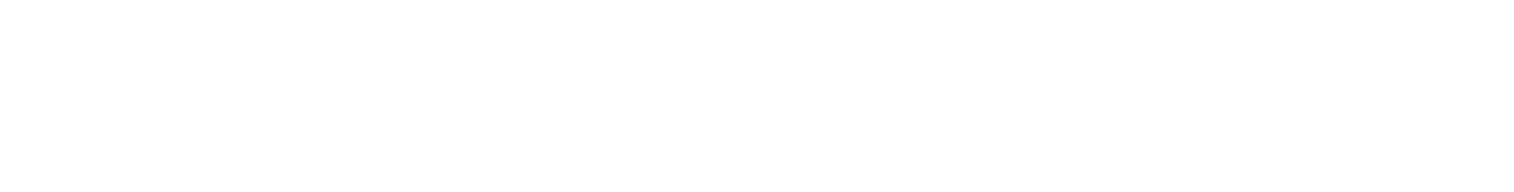

\section{المالغص}

لجريت هذه الدرلسة لقيم التأثير المقارن لعقاري اللزغوبريل والتلهسارتن لُحابي العلاج على إجهاد

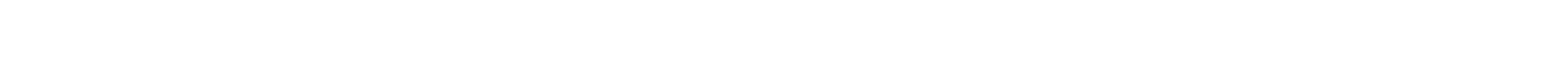

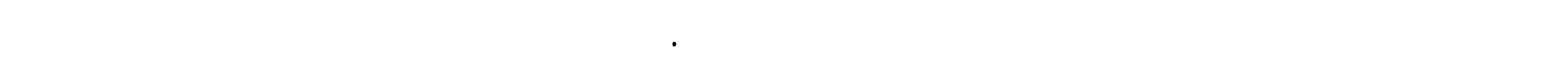
خلل فترة البمث بينشهري تشرين الثافي 2010 وحزيران 2011.شملت الدرلسة الحالية 82 مريضا، 43

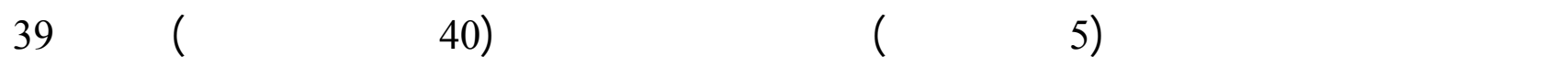

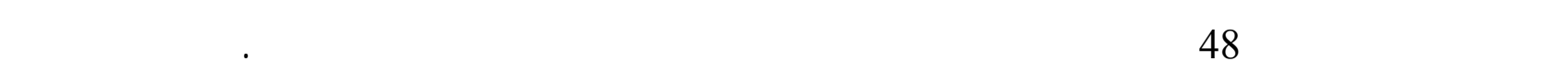
المالوندايالديهايد ومستوى مضادات الأكسة الكلي في مصل الدم قل وبعدشهر ولحد من من الإستمرار بالعلاج 
بالنبة للمرضی، في حين قيسوا لمرة ولحة بالنسبة لمجموعة اللسطرة. كثفت نتائج هـ ذه الدرلس بة بـ أن

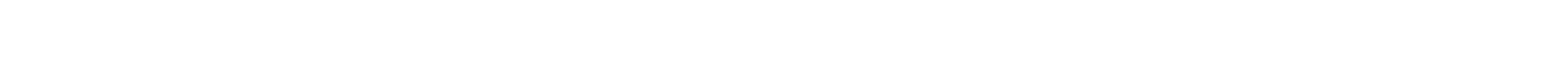

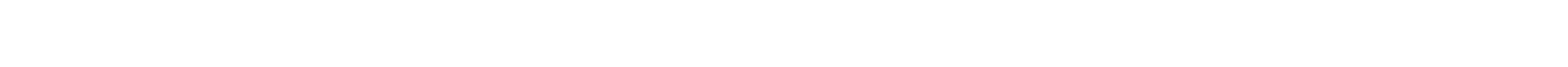

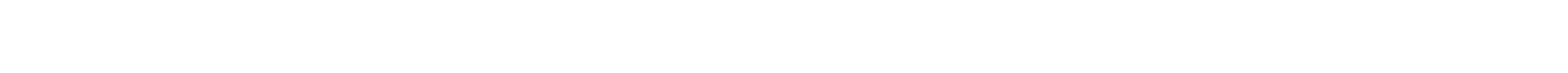

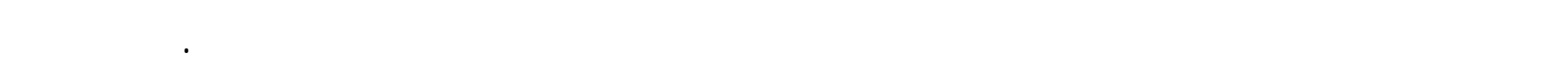

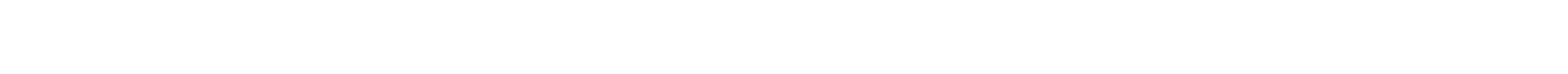
النوع الثاني وضغط الدم.

\section{الكاملت الدالة: ضغط الدم، مرض للسكري، مالوندليالييهايد، حالة مضادات الأكسة الكلي.}

\section{INTRODUCTION}

Diabetes is a non communicable, serious disease which is called a "silent killer" (ADA, 2011). It is common in Iraqi population with prevalence of 9.1\% (Mula-Abed and Al-Naemi, 2005). Diabetes mellitus and hypertension are common clinical conditions that often co-exist. This combination has been called the deadly duet to emphasise the increased cardiovascular risk when the two conditions co-exist (Ker, 2011). Oxidative stress (OS) is an imbalance between the production oxidants and antioxidant defenses in favor of the former (Montes-Cortes et al., 2010). Hyperglycaemia can induce oxidative stress and depression of natural antioxidant defenses like vitamin $\mathrm{C}$ and glutathione (Garg et al., 2010). Aside from scavenging nitric oxide (NO) in cardiovascular system, increases in reactive oxygen species (ROS) within the central nervous system may also directly activate or sensitize sympathetic neurones causing hypertension, premature atherosclerosis and other vascular disorders (Peterson et al., 2006). Changes in antioxidant levels in diabetes-related cardiovascular disease resulting in enhancement of procoagulant tissue factors and proinflammatory mediators that lead to endothelial dysfunction, smooth muscle proliferation and cardiovascular disease (Nwose et al., 2007).

Association between rennin angiotensin aldosterone system (RAAS) and ROS has been investigated extensively. Ang II induces production of ROS (Ruiz-Ortega et al., 2006), and it is a potent inducer of oxidative stress. Ang II stimulates Nicotine Amide Adenine Dinucleotide Phosphate (NADPH) oxidase expression and activity, as well as superoxide production in cells of vascular wall and coronary microvascular endothelial cells (Polikandrioti et al., 2005). Furthermore prolonged effects of Ang II can reduce the expression of defense system against ROS such as superoxide dismutase (Zimmerman et al., 2004). Moreover, increased level of ROS intern may stimulate the expression of components of RAAS favoring Ang II (Ogawa et al., 2009). Angiotesine converting enzyme inhibitors and angiotensin II receptor blockers are believed to have important antioxidant properties superior to those of vitamin $\mathrm{E}$ and other antioxidants (Khan, 2007).

The aim of the current study is to compare between the effects of lisinopril and telmisartan on malondialdehyde (MDA) and Total Antioxidant Status (TAS) in diabetic type 2 hypertensive patients. 


\section{MATERIAL AND METHOD}

Forty three patients (23 male, 20 female) whose ages between 35 and 71(mean age $52.2 \pm 9.23$ ) years kept on lisinopril $5 \mathrm{mg}$ (Lisino ${ }^{\circledR}$, Jamjoom Pharma, Saudi Arabia), once daily for one month. Whereas 39 persons ( 21 male, 18 female), ages of them ranges from 37 and 68 years with mean age $48.99, \mathrm{SD} \pm 10.15$ were received telmisartan $40 \mathrm{mg}\left(\mathrm{Telmi}^{\circledR}\right.$, Diamond Pharma, Syria ), taken in the same way and period of lisinopril. For standardization and comparison, 48 apparently healthy individuals, neither smokers nor alcoholics, matched for sex and age with the patient groups, were taken as controls (25males and 23 females) with age range from 35-69 years, and mean age \pm SD of $49.16 \pm$ 10.51 .

Serum MDA levels were estimated using TBA assay method (Badcock et al., 1997), whereas total antioxidant status was measured according to the method described by Miller and colleagues (Miller et al., 1993).

The statistical data obtained in the current study was analyzed using SPSS program (version 17). Standard statistical methods were used to determine the mean and standard deviation which summarized continuous data. Paired, unpaired t-test and linear regression analysis (r) were performed to identify the relationships between different parameters. Pvalue $\leq 0.05$ was considered to be statistically significant (Kirkwood, 1988).

\section{RESULTS}

The studied samples consist of 82 patients with type- 2 diabetes mellitus and 48 healthy subjects as a control group. The diabetic patients were divided in to two groups; the first group (43) were allocated on lisinopril and the second group (39) were given telmisartan.

Table (1) shows the number and percentage of males and females of both diabetic and control groups reflecting insignificant differences.

Table 1: Comparison of gender distributions between the studied groups.

\begin{tabular}{|c|c|c|c|c|c|}
\hline \multirow{2}{*}{ Gender } & \multicolumn{2}{|c|}{ Male } & \multicolumn{2}{c|}{ Female } & \multirow{2}{*}{ P-value } \\
\cline { 2 - 5 } & number & \% & Number & \% & \multirow{2}{*}{0.1} \\
\hline Diabetics & 44 & $53.65 \%$ & 38 & $46.35 \%$ & \\
\hline Control & 26 & $54.2 \%$ & 22 & $45.8 \%$ & \\
\hline
\end{tabular}

Table (2) manifests the number and percentage of males and females of both diabetic groups treated by lisinopril or telmisartan and reflecting insignificant differences.

Table 2: Baseline gender distribution between diabetic groups.

\begin{tabular}{|c|c|c|c|c|c|}
\hline \multirow{2}{*}{ Gender } & \multicolumn{2}{|c|}{ Male } & \multicolumn{2}{c|}{ Female } & \multirow{2}{*}{ P-value } \\
\cline { 2 - 5 } & number & $\%$ & Number & $\%$ & \\
\hline Lisinopril & 23 & $53.48 \%$ & 21 & $46.58 \%$ & \multirow{2}{*}{0.5} \\
\hline Telmisartan & 21 & $53.8 \%$ & 18 & $46.2 \%$ & \\
\hline
\end{tabular}


Table (3) indicates that there is no significant differences between diabetic and control groups regarding age and BMI.

Table 3 : Comparison of age and BMI between the studied groups.

\begin{tabular}{|c|c|c|c|c|c|}
\hline \multirow{2}{*}{ parameters } & \multicolumn{2}{|c|}{$\begin{array}{c}\text { Diabetic patients } \\
\mathbf{N = 8 2}\end{array}$} & \multicolumn{2}{c|}{$\begin{array}{c}\text { Control group } \\
\mathbf{N}=\mathbf{4 8}\end{array}$} & \multirow{2}{*}{ P-value } \\
\cline { 2 - 6 } & Mean (SD) & $\begin{array}{c}95 \% \text { CI of } \\
\text { mean }\end{array}$ & Mean (SD) & $\begin{array}{c}95 \% \text { CI of } \\
\text { mean }\end{array}$ & \\
\hline Age & $51.37(9.61)$ & $49.26-53.49$ & $49.16(10.51)$ & $45.92-52.39$ & 0.2 \\
\hline BMI & $31.29(5.28)$ & $30.13-32.45$ & 30.454 .76 & $28.99-31.92$ & 0.3 \\
\hline
\end{tabular}

Table (4) warrants insignificant differences regarding age and body mass index (BMI) between diabetic groups treated by lisinopril or telmisartan.

Table 4 : Comparison of age and BMI between diabetic groups.

\begin{tabular}{|c|c|c|c|}
\hline parameters & $\begin{array}{c}\text { Lisinopril group N=43 } \\
\text { Mean (SD) }\end{array}$ & $\begin{array}{c}\text { Telmisartan group N=39 } \\
\text { Mean (SD) }\end{array}$ & P-value \\
\hline Age & $52.2(9.23)$ & $48.97(10.15)$ & 0.1 \\
\hline BMI & $31.45(5.46)$ & 30.48 & 0.2 \\
\hline
\end{tabular}

Table (5) indicates that there is significant differences between diabetic and control groups regarding serum MDA and TAS.

Table 5 : Comparison of MDA and TAS between the studied groups.

\begin{tabular}{|c|c|c|c|}
\hline parameters & $\begin{array}{c}\text { Diabetic patients N=82 } \\
\text { Mean } \pm \text { SD }\end{array}$ & $\begin{array}{c}\text { Control group N=48 } \\
\text { Mean } \pm \text { SD }\end{array}$ & P-value \\
\hline MDA & $1.48 \pm 0.89$ & $1.00 \pm 0.52$ & $<0.0001$ \\
\hline TAS & $1.122 \pm 0.58$ & $1.47 \pm 0.16$ & $<0.0001$ \\
\hline
\end{tabular}

Table (6) displays that there was a significant decrease in serum MDA levels after one month of therapy with either lisinopril or telmisartan. 
Table 6: Comparison of serum MDA changes between lisinopril and telmisartan administered groups before and after treatment.

\begin{tabular}{|c|c|c|c|c|}
\hline \multicolumn{2}{|c|}{ Medication } & Mean (SD) & Mean difference & P-value \\
\hline \multirow{2}{*}{ Lisinopril } & Before & $1.41(1.03)$ & & \\
\cline { 2 - 3 } & After & $1.10(0.88)$ & 0.30 & $<0.0001$ \\
\hline \multirow{2}{*}{ Telmisartan } & Before & $1.57(0.69)$ & & $<0.0001$ \\
\cline { 2 - 3 } & After & $1.08(0.519)$ & & \\
\hline
\end{tabular}

Table (7) shows that there was a significant increase in serum TAS levels after one month of therapy with lisinopril or telmisartan.

Table 7: Comparison of serum TAS changes between lisinopril and telmisartan administered groups before and after treatment.

\begin{tabular}{|c|c|c|c|c|}
\hline \multirow{2}{*}{ Medication } & & Mean (SD) & $\begin{array}{c}\text { Mean } \\
\text { difference }\end{array}$ & P-value \\
\hline \multirow{2}{*}{ Lisinopril } & Before & $1.143(0.61)$ & \multirow{2}{*}{-0.41} & $<0.0001$ \\
\cline { 2 - 3 } & After & $1.38(0.67)$ & & $<0.0001$ \\
\hline \multirow{2}{*}{ Telmisartan } & Before & $1.106(0.64)$ & -0.45 & \\
\cline { 2 - 3 } & After & $1.394(0.51)$ & & \\
\hline
\end{tabular}

\section{DISCUSSION}

The assessment of oxidative stress in both diabetes and hypertension has become crucial as an index of pathology of these diseases (Ceriello, 2006).

The results obtained showed that the studied subjects had significantly higher levels of MDA and low levels of TAS when compared with the negative controls as showed in table (5). In a dramatic manner they also showed that the high levels of MDA were decreased significantly as showed in table (6) and there is also significant increase in the low levels of TAS after only one month of therapy with either lisinopril or telmisartan as in showed in table (7).

These data encouraged many earlier works. Noda et al., in 1997 demonstrated scavenging activity of lisinopril with increased glutathione (GSH) and decreased MDA levels noting that lisinopril playing the role of antioxidant. Waanders et al., (2008) found that lisinopril, spironolactone and the combined treatment all tended to reduce urinary MDA levels compared to vehicle, without differences between the groups. In 2006 Takaya et al. reported antioxidant role of telmisartan. There after Ceriello et al., in 2007 proved that 
telmisartan works as an antioxidant like vitamin C. Recently in 2011, Al-Amran et al., and after 8 weeks of rats treatment with telmisartan was found a significant reduction of MDA level, and significant increased in GSH content and the catalase enzyme activity.

Angitensin converting enzyme inhibitors and Angiotesin receptor blocker may act as "magic bullets" against oxidative stress and this may explain some of their beneficial effects that cannot be associated to their action on blood pressure (Mohammadi-Bardbori and Ghazi-Khansari, 2007). The mechanism of this specific protection is not yet understood. Various studies suggested that ACEIs and ARBs may affect ROS by antioxidant effect through the free radical scavenger action or inhibition of molecules adhesion. They could also modulate reactive oxygen and nitrogen species generation by inhibiting the stimulation of vascular NADPH oxidase, another predictable effect of ACEIs would be to reduce the ambient levels of superoxide in the vascular wall (Polizio and Pena, 2007).

Lisinopril itself inhihibits lipid peroxidation, elevated tissue glutathione levels, and influenced the activity of antioxidant enzymes such as catalase and glutathione peroxidase (Polizio and Pena, 2007). The ability of telmisartan to activate Peroxisome proliferator activated receptors PPAR $\gamma$ appears to be independent of Angiotensin I receptor (AT1R) blockade (Schupp et al., 2005). The PPAR $\gamma$ activation induces the catalase gene expression and protein. The inducibility of the catalase gene could play an important role in combating the oxidative stress (Nakamura et al., 2005; Jung et al., 2007).

\section{CONCLUSION}

Both lisinopril and telmisartan have good efficacy against oxidative stress with no significant differences between them, they possibly be suitable agents for patients with diabetes and hypertension.

\section{REFERENCES}

ADA (American Diabetes Association) (2011). Annual American Diabetes Association Alert Days. Diab. Inf., 1, 2-14.

Al-Amran, G.F.; Hadi, R.N.; Kamoona, H.T.; Kadhum, J.Z. (2011). Amelioration of chronic cyclosporine A-induced nephrotoxicity by telmisartan in rats. Af. $J$. Phar. and Pharmacol., 5(4), 502-511.

Buege, J.A.; Aust, S. D. (1978). Thiobabituric acid assay. Meth. Enzymol., 52, 306307.

Ceriello, A. (2006). Oxidative stress and diabetes-associated complications. Endo Pract., 12, 60-61.

Ceriello, A.; Piconi, L.; Esposito, K.; GiuglIano, D. (2007). Telmisartan shows an equivalent effect of vitamin $\mathrm{C}$ in further improving endothelial dysfunction after glycemia normalization in type 1 diabetes. Diab. Car. , 30, 1694-1699.

Garg, R.G.; Khanna, N.; Mehta, K.D.; Arora, T.; Sharma, S.B.; Sharma, K.K. (2010). Modulation of oxidative stress, serum lipids and renal dysfunction by benazepril in diabetes mellitus. J. K. Sci., 12, 13.

Jung, K.; Chu, K.; Lee, S.; Kim, S.; Song, E.; Kim, E. (2007). Blockade of AT1 receptor reduces apoptosis, inflammation, and oxidative stress in normotensive rats with intracerebral hemorrhage. Pharm. and Experim. Therap., 322. 10571063. 
Ker, J.A. (2011). Management issues in hypertensive diabetics. C.I.M.E.D. 53 (2), 144-165.

Khan, A. (2007). "Cardiac drug therapy" 7th ed., Humana Press, New Jursey, pp 46.

Kirkwood, B.R. (1988). "Essentials of Medical Statistics". 1st edn., Blackwell scientific publication, Oxford, pp 43-56.

Miller, N. J.; Rice-Evans, C.; Davies, M. J.; Gopinathan, V.; Milner, A. (1993). A novel method for measuring antioxidant capacity and its application to monitoring the antioxidant status in premature neonates. Clin. Sci., 84, 407412.

Mohammadi-Bardbori, A.; Ghazi-Khansari, M. (2007). Nonthiol ACE inhibitors, enalapril and lisinopril are unable to protect mitochondrial toxicity due to paraquat. Pest. Bio. and Physiol., 89, 163-171.

Montes-Cortes, D.H.; Hicks, J.J.; Ceballos-Reyes, M.G.; Garcia-Sanchez, R.J.; Medina-Navarro, R.; Olivares-Corichi, M.I. (2010). Chemical and functional changes of human insulin by in vitro incubation with blood from diabetic patients in oxidative stress. Met. Clin. and Exp., 10, 1-9.

Mula-Abed, W.S.; Al-Naemi, A.H. (2005). Prevalence of Diabetes Mellitus in Mosul City Comparison of 1997 ADA Classification with 1985 WHO Classification. Diab. Dig. IRAQ., 5, 1-8.

Nakamura, T.; Keep, R.F.; Hua, Y.; Hoff, J.T.; Xi, G. (2005). Oxidative DNA injury after experimental intracerebral hemorrhage. Br. Res., 21, 32-38.

Noda, Y,; Mori, A.; Packer, L. (1997). Free radical scavenging properties of alacepril metabolites and lisinopril. Res. Commun. Mol. Pathol. Pharmacol., 96, 125129.

Nwose, E.; Jelinek, H.; Richards, R.; Kerr, P. (2007). Erythrocyte oxidative stress in clinical management of diabetes and its cardiovascular complications. Br. J. Biomed. Sci., 64, 35-44.

Ogawa, S.; Kobori, H.; Johashi, N.; Urushihara, M.; Nishiyama, A.; Mori, T. (2009). Angiotensin II type 1 receptor blockers reduce urinary angiotensinogen excretion and the levels of urinary markers of oxidative stress and inflammation in patients with type 2 diabetic nephropathy. Bio. Ins., 4, 98-106.

Peterson, J.R.; Sharma, R.V.; Davisson, R.L. (2006). Reactive oxygen species in the neuropathogenesis of hypertension. Curr. Hypertens. Rep., 8, 232-241.

Polikandriotis, A.G.; Rupnow, L.H.; Elms, C.S.; Clempus, E.R.; Campbell, J.D.; Sutliff, L.R. (2005). Chronic ethanol ingestion increases superoxide production and NADPH oxidase expression in the lung. Hypertens., 34, 316-322.

Polizio, H.A.; Pena, C. (2007). Lisinopril as an antioxidant in hypertension?. Antioxd. and Red. Sign., 9(3), 394-398.

Ruiz-Ortega, M.; Ruperez, M.; Sanchez-Lopez, V.E.; Rodríguez-Vita, J.; Carvajal, G. (2006). Angiotensin II as a novel proinflammatory factor in chronic diseases. Inflamm. and Chr. Dis., 2, 4-13.

Schupp, M.; Clemenz, M.; Gineste, R. (2005). Molecular characterization of new selective peroxisome proliferator-activated receptor $\gamma$ modulators with angiotensin receptor blocking activity. Diab., 54, 3442-3447. 
Takaya, T.; Kawashima, S.; Shinohara, M.; Yamashita, T. (2006). Angiotensin II type 1 receptor blocker telmisartan suppresses superoxide production and reduces atherosclerotic lesion formation in apolipoprotein E-deficient mice. Atherosc., 186, 402-409.

Waanders, F.; Hoven, J.M.; Rops, L.A.; Kramer, B.A.; Goor, H.; Berden. H.J. (2008). Regulation of glumerular heparanase expression by aldosterone, Angiotensin II and reactive oxygen species. Nephrol. Dial. Transplant., 7, 86-92.

Zimmerman, M.C.; Lazartigues, E.; Sharma, R.V.; Davisson, R.L. (2004). Hypertension caused by angiotensin II infusion involves increased superoxide production in the central nervous system. Circ Res., 95, 210-217. 